\title{
CRYSTAL LATTICE ROTATIONS DURING PLASTIC DEFORMATION OF TWO-DIMENSIONAL POLYCRYSTALLINE AI SAMPLES
}

\author{
E.E. Badiyan, Ye.V. Ftomov, O.V. Shekhovtsov, A.G. Tonkopryad \\ V.N. Karazin Kharkiv National University, Kharkiv, Ukraine \\ E-mail: Evgeny.E.Badiyan@univer.kharkov.ua; tel. +38(057)707-53-47
}

\begin{abstract}
Theoretical studies of feasible rotations of the crystal lattice during the deformation of samples with an FCC structure under uniaxial tension are carried out. The results of the experimental determination of the magnitudes of these rotations for various grains of two-dimensional polycrystalline aluminum samples after their deformation by the same strain value are presented. For the first time, it has been theoretically shown and experimentally confirmed that under uniaxial tension of a specimen under the conditions of operation of only one slip system, regardless of the scheme of rotation, the magnitude of the rotation is determined only by the angle between the direction of the tensile axis and the slip direction before deformation of the specimen.
\end{abstract}

PACS: 61.82.Bg, 62.20.F-, 61.72.Lk

\section{INTRODUCTION}

Crystal lattice rotations always accompany plastic deformation of samples. They are characterized by the magnitude of the angle and direction of the rotation. The problem of studying the patterns of rotation of the crystal lattice during plastic deformation seems important enough, since they not only change the value of the Schmid factor for the existing slip system, but also the nature of its distribution for other slip systems, which can change the pattern of development of plastic deformation and, ultimately, mechanical characteristics. The question of the combination of possible active slip systems is still open. The results of well-known experimental studies of the patterns of crystal lattice rotations accompanying the plastic deformation of crystalline samples are quite contradictory $[1,2]$.

Thus, in [1], based on the analysis of experimentally obtained paths of the axis of tension of the sample for various grains of a polycrystalline aluminum sample during its deformation, it was shown that the rotations in the central regions of the grains are characterized by the lowest speed, and the direction of the rotations indicates the operation of secondary slip systems. It was shown in [2] that the lattice rotations strongly depend on the crystallographic orientation of the grain before deformation of the sample.

With the help of stereographic projections of various paths of a rotation and visualization of the orientation dependence of the Schmid factor, a theoretical and experimental study of the patterns of rotations of the lattice of FCC crystals during plastic deformation of samples by uniaxial tension at a constant speed is carried out.

\section{DIFFERENT SCHEMES OF CRYSTAL LATTICE ROTATION DURING THE DEFORMATION OF SINGLE-CRYSTAL SAMPLES WITH FCC STRUCTURE}

At first sight, it is obvious, and this is theoretically shown that during the rotations of single-crystal samples in process of their plastic deformation by sliding, the tensile axis rotates in the direction of sliding, forming an angle $\lambda$ with it. Certainly, this can only occur when only one slip system is operating. When more than one slip system is operating, the direction of rotation of the crystal lattice is the resultant interaction of various existing slip systems.

Fig. 1 shows, with the help of the standard stereographic triangle, that, depending on the initial crystallographic orientation of the tensile axis of the sample during plastic deformation, three different schemes of its rotation are possible.

1. The rotation takes place in the plane passing through the axis of tension, the direction of the primary slip system [101], the direction of the conjugate slip system [110] and the direction [211], for which the primary and conjugate slip system become equal. The value of the Schmid factor for these systems is the same and is 0.41 . This rotation is the only one.

2 . In the second rotation scheme, the direction of tensile axis, the direction of primary slip [101] and the normal to the conjugated slip plane [11] should be in the same plane. This way of rotation is also the only one.

3. For the third scheme of crystal lattice rotation of a single-crystal sample, it is necessary that only the axis of tension of the sample and the direction of primary slip [101] be in the same plane. There are countless rotation paths of such type.

For any type of rotation of the crystal lattice, when the projection of tensile axis reaches the [100] - [111] line, the direction of rotation should change. Due to the equal significance of the primary and conjugate slip systems, the tensile axis must move in the [111] direction. The criterion for the equal significance of primary and conjugate slip systems is the equality for them of Schmid factors for all points on the side of the stereographic triangle [100] - [111] (see Fig. 1).

The maximum possible magnitude of a sample rotation in one direction during its deformation is achieved when the projection of the tensile axis before deformation is on the side of the stereographic triangle [100] - [110] and depends on the scheme of rotation. Fig. 1 shows that in the case of a rotation according to scheme $A$, the maximum possible magnitude of a rotation can be $30^{\circ}$, according to scheme $B \approx 19^{\circ}$, according to scheme $C$ up to $30^{\circ}$.

Certainly, such magnitude of the maximum possible rotation of a single-crystal sample during its deformation cannot be physically reached. It is limited by the possible value of plastic strain of the sample. 


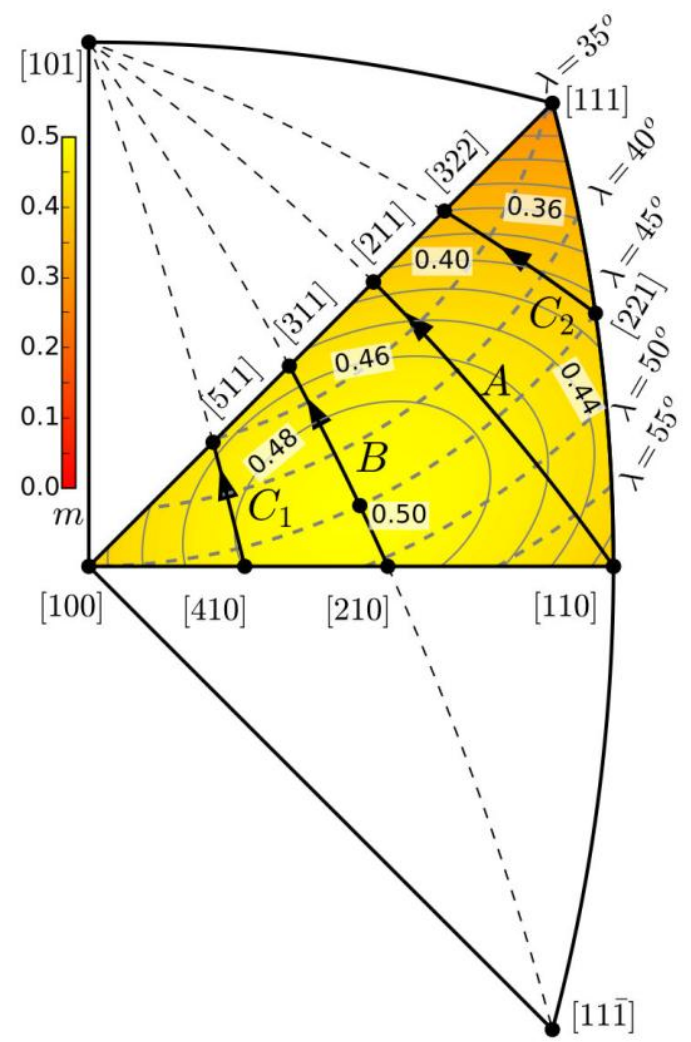

Fig. 1. Different schemes of rotation $\left(A, B, C_{1}, C_{2}\right)$ of the crystal lattice during plastic strain of samples with FCC structure

\section{THE RELATIONSHIP BETWEEN RELATIVE STRAIN AND THE MAGNITUDE OF THE CRYSTAL LATTICE ROTATION}

Due to the fact that the cause of the rotation of the axis of tension of the sample is its strain, one can determine the dependence of the angle of this rotation on the magnitude of the strain. It is easy to show $[3,4]$ that under the conditions of plastic uniaxial tension by sliding of a single-crystal sample, the relation holds:

$$
l_{1} / l_{0}=\sin \lambda_{0} / \sin \lambda_{1},
$$

where $l_{0}$ and $l_{1}$ is the length of the sample before and after the tension; $\lambda_{0}$ and $\lambda_{1}$ the angles between the axis of tension $\sigma$ and the direction of the primary slip [101] before and after its strain, respectively.

Expression (1) can be written as follows:

$$
\begin{aligned}
& \left(l_{1}-l_{0}\right) / l_{0}=\left(\sin \lambda_{0}-\sin \lambda_{1}\right) / \sin \lambda_{1} \\
& \text { or } \sin \lambda_{1}=\left(\sin \lambda_{0}\right) /(1+\varepsilon),
\end{aligned}
$$

where $\varepsilon=\left(l_{1}-l_{0}\right) / l_{0}$ is the value of the relative strain of the sample.

The resulting expression (2) shows that the rotation of a single-crystal sample $\Delta \lambda=\lambda_{0}-\lambda_{1}$ occurring during its deformation depends on the magnitude of plastic strain $\varepsilon$, and the value of the angle $\lambda_{0}$ between the direction of tension $\sigma$ and the direction of primary slip before deformation. The result shows that when the same value of plastic strain is achieved, the magnitude of the crystal lattice rotation in single-crystal samples or individual polycrystal grains should be determined only by the angle $\lambda_{0}$ between the axis of tension of the sample and the slip direction before deformation.

Fig. 2 shows the plots characterizing the change in the Schmid factor $m$ during plastic strain of a singlecrystal sample, depending on the magnitude of rotation $\Delta \lambda$ for different schemes of this rotation. Primarily attention is drawn to the fact that these dependencies are non-monotonic in nature and have an extremum (maximum).

To determine the extremum points, an orthogonal coordinate system $\mathrm{X}, \mathrm{Y}, \mathrm{Z}$ is chosen in which the $\mathrm{Z}$ axis is parallel to the primary slip direction [101], the $X$ axis

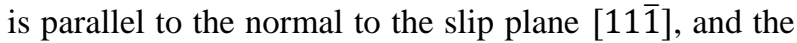
spherical coordinate system in which the direction of the tension axis $\vec{\sigma}$ is determined by the zenith angle $\lambda$ and azimuth angle $\varphi$ (Fig. 3).

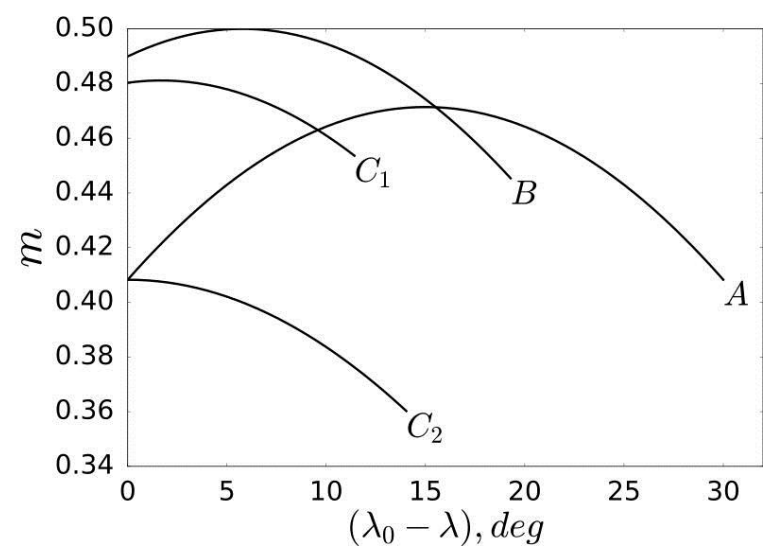

Fig. 2. The change of the Schmid factor $m$ as a result of the rotation of the crystal lattice $\Delta \lambda=\lambda_{0}-\lambda$ during the process of strain of the sample for different rotation schemes shown in Fig. 1

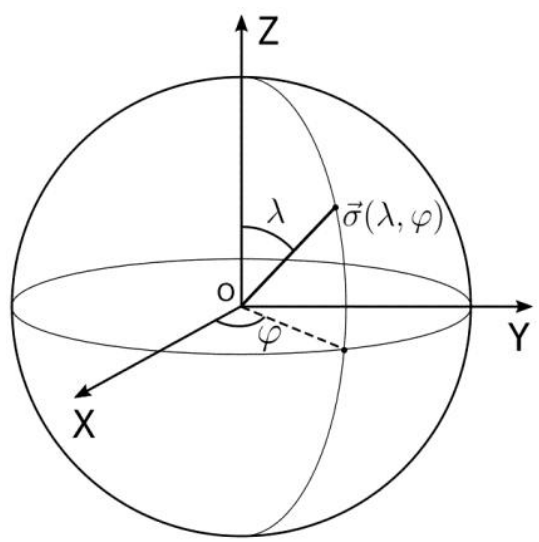

Fig. 3. Orientation of the tensile axis $\vec{\sigma}=\vec{\sigma}(\lambda, \varphi)$ of the specimen in a spherical coordinate system $(\lambda, \varphi)$

The direction of the axis of tension $\vec{\sigma}$ can be determined as follows:

$$
\vec{\sigma}=\vec{\sigma}(\lambda, \varphi)=\left[\begin{array}{c}
\sin \varphi \sin \lambda \\
\cos \varphi \sin \lambda \\
\cos \lambda
\end{array}\right] .
$$

And the expression for the Schmid factor can be written as follows:

$m(\lambda, \varphi)=|(\vec{\sigma}, \vec{x}) \cdot(\vec{\sigma}, \vec{z})|=|\sin \varphi \cdot \sin \lambda \cdot \cos \lambda|$, where angle $\lambda$ characterizes the magnitude of the rotation, and $\varphi$ the direction (scheme) of the rotation. 
The maximum values of the Schmid factor can be found from the condition:

$$
\begin{gathered}
\frac{d m}{d \lambda}=0, \\
\frac{d m}{d \lambda}=|\sin \varphi \cdot \cos \lambda \cdot \cos \lambda-\sin \varphi \cdot \sin \lambda \cdot \sin \lambda|=0 .
\end{gathered}
$$

Which implies that:

$$
\cos \lambda=\sin \lambda \Rightarrow \lambda_{\max }=45^{\circ} .
$$

Thus, the maximum values of the Schmid factor for all feasible schemes of rotation corresponds to an angle of $\lambda=45^{\circ}$.

Thus, for values of $\lambda<45^{\circ}$, the Schmid factor increases during the process of the rotation of the crystal lattice, regardless of the scheme of rotation, and for values $\lambda>45^{\circ}$, the rotation of the crystal lattice during strain of the sample is accompanied by a decrease in $m$. The stereographic projection of the tensile axis corresponding to $\lambda=45^{\circ}$ is shown as dashed line in Fig. 1.

Fig. 4 shows the dependence of the magnitude of the rotation of the axis of tension of a single-crystal sample on the value of relative plastic strain $\varepsilon$ and angle $\lambda_{0}$ between the direction of primary slip and the direction of tension before deformation of the sample. The abscissa shows the relative plastic strain from 0 to $30 \%$. The value of $30 \%$ is the maximum plastic strain resource for typical single-crystal samples with an FCC lattice such as copper and aluminum. From this graph it follows that the maximum value of the rotation of specimen tensile axis is achieved when a strain of $30 \%$ does not exceed $\approx 18^{\circ}$ in case of $\lambda_{0}=60^{\circ}$. These are overestimated values provided that the strain of the sample is achieved under the conditions of operation of only one slip system. As mentioned above, when other additional sliding systems are activated, the magnitude and direction of rotation can change.

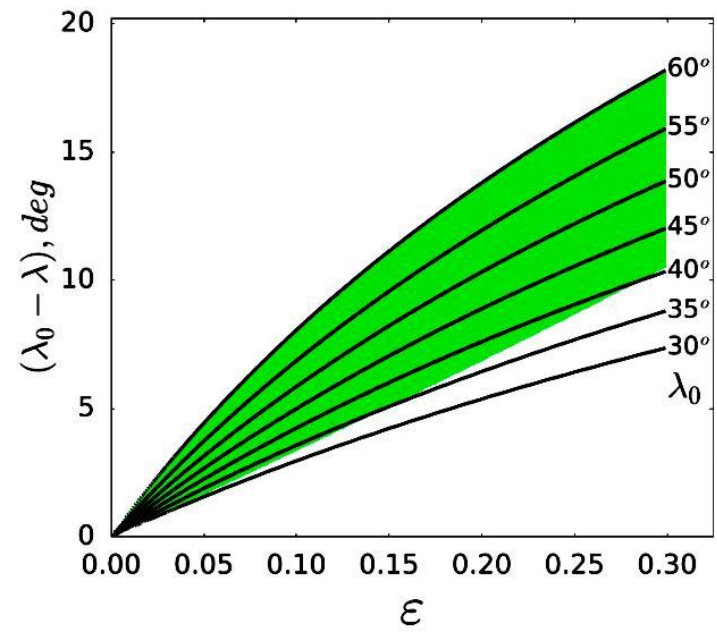

Fig. 4. The dependence of the magnitude of the rotation of the crystal lattice $\Delta \lambda=\lambda_{0}-\lambda$ on the relative strain $\varepsilon$ and $\lambda_{0}$, where $\lambda_{0}$ is the angle between the direction of the tensile axis and the direction of primary slip before the strain of the sample. The area of physically possible values of $\Delta \lambda$ is shaded (see Fig. 1)

\section{EXPERIMENTAL RESULTS}

To verify the above results for experimental studies, coarse-grained aluminum samples (purity 99.98\%) were obtained by a special method [5] of recrystallization. The average grain size in the samples is $7 \ldots 10 \mathrm{~mm}$. The dimensions of the working part of the samples are $100 \times 20 \times 0.15 \mathrm{~mm}$. With this thickness, the samples have a parquet structure containing only through grain boundaries. It is well known that in such samples, due to the lack of tightness in the direction perpendicular to the surface of the sample, the rotational component of deformation predominates most often during their deformation at the initial stage, and only the primary slip system operates [6]. In order to detect substructural and orientational changes using optical techniques $[7,8]$ and to register the occurrence and development of dislocation glide [9, 10], one of the working (side) surfaces was carefully polished, and the second one after polishing was chemically etched to reveal a quasiperiodic structure. All samples were deformed under conditions of active tension at a constant rate of $\sim 10^{-5} \mathrm{c}^{-1}$ and upon reaching the strain of $10 \%$ were unloaded. Due to the fact that the relative deformation of grains even within the same sample can be different and differed from the deformation of the entire sample, grains with the same relative plastic strain $\varepsilon$ were chosen for research. In the central region of each grain, before and after deformation of the sample by the Laue X-ray method, the crystallographic orientation of the tensile axis was determined and the values of the Schmid factor $m$ and angles $\lambda_{0}, \Delta \lambda$ were calculated. The error in determining the magnitude of the rotation did not exceed $1^{\circ}$.

In seven of the 35 grains studied for different polycrystalline aluminum samples after their deformation by $7 \%$ revealed the formation of a fragmented structure. The orientation of the tensile axis for these grains is near the side of the stereographic triangle [100]-[111]. In the remaining grains, the crystal lattice was rotated by a different value of $\Delta \lambda$. Primarily it should be noted that that the magnitude of the rotation $\Delta \lambda$ found to be independent of the Schmid factor, which is characterized by the crystallographic orientation of the grain. So in twelve grains with the same value of the Schmid factor, the magnitude of the rotation was different. In 16 grains with different values of the Schmid factor, but with approximately the same angle $\lambda_{0}$, the magnitude of the rotation $\Delta \lambda$ turned out to be almost the same.

\section{CONCLUSIONS}

1. In the process of plastic strain of polycrystalline samples with an FCC lattice, three different crystal lattice rotation schemes are possible. For the first scheme, the rotation takes place in the plane passing through the axis of tension, the direction of the primary slip system [101], the direction of the conjugate slip system [110] and the direction [211], for which the primary and conjugate slip system become equal. The value of the Schmid factor for these systems is the same and is 0.41 . This rotation is the only one. For the second rotation scheme, the direction of tensile axis, the 
direction of primary slip [101] and the normal to the conjugated slip plane [111] should be in the same plane. This way of rotation is also the only one. For the third scheme of crystal lattice rotation of a single-crystal sample, it is necessary that only the axis of tension of the sample and the direction of primary slip be in the same plane [101]. There are countless rotation paths of such type.

2. It is shown that, in contrast to the well-known concepts, the magnitude of the crystal lattice rotation does not depend on the crystallographic orientation of the tensile axis, but is a function of the relative grain strain and the angle between the tensile axis and the slip directions before the deformation of the sample.

3. A non-monotonic dependency of the Schmid factor on the magnitude of the rotation $\Delta \lambda=\lambda_{0}-\lambda$ of the crystal lattice was found. Its maximum value, regardless of the rotation scheme, attained at $\lambda=45^{\circ}$.

4. The experimentally studied patterns of crystal lattice rotations during plastic strain of samples of typical FCC aluminum crystals showed quite good agreement with the results of theoretical studies.

\section{REFERENCES}

1. В.В. Рыбин, Ю.Ф. Титовец, Н.Ю. Золоторевский, А.Н. Самойлов. Скольжение и повороты решетки в пластически деформируемом поликристалле алюминия // Дисклинаџии $u$ ротационная деформация твердых тел. Л.: изд-во ФТИ им. А.Ф. Иоффе, 1990, с. 205-214.

2. J.H. Han, K.K. Jee, and K.H. Oh. Orientation rotation behavior during in situ tensile deformation of polycrystalline 1050 aluminum alloy // International Journal of Mechanical Sciences. 2003, v.45(10), p. 1613-1623.

3. R.W.K. Honeycombe. The plastic deformation of metals. 2nd ed. 1984, 483 p.
4. F. Von Göler, G. Sachs. Das Verhalten von Aluminiumkristallen bei Zugversuchen // Zeitschrift für Physik A Hadrons and Nuclei. 1927, v. 41(2-3), p. 103115.

5. E.E. Badiyan, A.G. Tonkopryad, T.R. Zetova, R.V. Shurinov, S.V. Talakh, A.V. Dergacheva. Features of structure of copper two-dimensional polycrystals obtained by recrystallization method and nature of its changes in process of plastic deformation // PAST. Series "Vacuum, Pure Materials, Superconductors". 2016, N 1(101), p. 88-91.

6. E.E. Badiyan, A.G. Tonkopryad, O.V. Shekhovtsov, R.V. Shurinov, T.R. Zetova, K.S. Kazachkova. Investigation of origination and development of the surface deformation relief of crystalline materials by laser radiation // Funct. Mater. 2015, v. 22(3), p. 396401.

7. Пат. 93021 Україна: МПК G01N 21/00, G01N 21/17, G01N 33/20. № a 201002923 . Спосіб визначення кристалографічної орієнтачії зерен на поверхні полікристалічного зразка. Заявл. 15.03.10; опубл. 27.12.10. Бюл. №24.

8. Пат. 89743 Україна: МПК G01B 11/16. № a 200906455 . Спосіб контролю орієнтаційних змін у кристалічних матеріалах "іп situ” в прочесі зовнішнього впливу. Заявл. 22.06.09; опубл. 25.02.10. Бюл. №4.

9. E.E. Badiyan, A.G. Tonkopryad, O.V. Shekhovtsov, R.V. Shurinov, T.R. Zetova. Optical Technique for the in situ study of orientation and structure changes accompanied the plastic deformation of polycrystalline specimens of aluminum // Inorganic Materials. 2011, v. 47(15), p. 1663-1666.

10. E.E. Badiyan, A.G. Tonkopryad, O.V. Shekhovtsov, R.V. Shurinov, T.R. Zetova, K.S. Kazachkova. Determination of characteristics of substructure and orientation inhomogeneity in polycrystalline specimens // Funct. Mater. 2014, v. 21(3), p. 307-312.

Статья поступила в редакичию 18.10 .2019 г.

\section{РАЗВОРОТЫ КРИСТАЛЛИЧЕСКОЙ РЕШЕТКИ ПРИ ПЛАСТИЧЕСКОМ ДЕФОРМИРОВАНИИ ДВУМЕРНЫХ ПОЛИКРИСТАЛЛИЧЕСКИХ ОБРАЗЦОВ АІ}

Е.Е. Бадиян, Е.В. Фтёмов, О.В. Шеховцов, А.Г. Тонкопряд

Проведены теоретические исследования возможных разворотов кристаллической решетки при деформировании образцов с ГЦК-структурой в условиях одноосного растяжения. Приведены результаты экспериментального определения величин этих разворотов для различных зерен двумерных поликристаллических образцов алюминия после их деформирования на одну и ту же величину. Впервые теоретически показано и экспериментально подтверждено, что при одноосном растяжении образца в условиях работы только одной системы скольжения независимо от схемы разворота величина разворота определяется только углом между осью растяжения и направлением скольжения до деформирования образца.

\section{РОЗВОРОТИ КРИСТАЛІЧНОЇ ГРАТКИ ПРИ ПЛАСТИЧНІЙ ДЕФОРМАЦЇ̈ ДВОВИМІРНИХ ПОЛІКРИСТАЛІЧНИХ ЗРАЗКІВ АІ \\ С.Ю. Бадіян, С.В. Фтьомов, О.В. Шеховцов, А.Г. Тонкопряд}

Проведено теоретичні дослідження можливих розворотів кристалічної гратки при деформації зразків із ГЦК-структурою за умов одновісного розтягування. Наведено результати експериментального визначення величин цих розворотів для різних зерен двовимірних полікристалічних зразків алюмінію після їхньог деформування на одну й ту ж саму величину. Вперше теоретично показано й експериментально підтверджено, що при одновісному розтягуванні зразка за умов, коли працює тільки одна система ковзання, незалежно від схеми розвороту величина розвороту визначається тільки кутом між віссю розтягування та напрямком ковзання до деформування зразка. 